\title{
A New Wind Vane for the Measurement of Atmospheric Turbulence
}

by

M. J. Parker

Westinghouse Savannah River Company

Savannah River Site

Aiken, South Carolina 29808

M. Heverly

Met One Instruments

OR USA

DOE Contract No. DE-AC09-96SR18500

This paper was prepared in connection with work done under the above contract number with the U. S.

Department of Energy. By acceptance of this paper, the publisher and/or recipient acknowledges the U.S. Government's right to retain a nonexclusive, royalty-free license in and to any copyright covering this paper, along with the right to reproduce and to authorize others to reproduce all or part of the copyrighted paper.

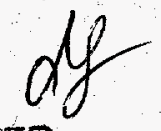




\section{DISCLATMER}

This report was prepared as an account of work sponsored by an agency of the United States Government. Neither the United States Government nor any agency thereof, nor any of their cmployees, makes any warranty, express or implied, or assumes any legal liability or. -responsibility for the accuracy, completeness, or usefulness of any information, apparatus, product, or process disclosed, or represents that its use would not infringe privately owned rights. Reference herein to any specific commercial product, process, or service by trade name, trademark, manufacturer, or otherwise does not necessarily constitute or imply its endorsement, recommendation, or favoring by the United States Government or any agency thereof. The views and opinions of authors expressed herein do not necessarily state or reflect those of the United States Govemment or any agency thereof.

This report has been reproduced directly from the best available copy.

Available to DOE and DOE contractors from the Office of Scientific and Technical Information, P.O. Box 62, Oak Ridge, TN 37831; prices available from (615) 57.6-8401.

Available to the public from the National Technical-Information Service, U.S. Department of Commerce, 5285 Port Royal Road, Springfield, VA 22161. 


\section{DISCLAMMIXR}

Portions of this document may be illegible in electronic image products. Images are produced from the best available original document. 
Distribution list for:

A New Wind Vane for the Measurement of Atmospheric Turbulence (U) WSRC-TR-97-0011

Dr. Susan Wood, 773-A

T. G. Wright, 773-A

J. G. Irwin, SRFS 760-G

P. T. Deason, 773-A

J. D. Heffner, 735-16A

R. E. DeBusk, 706-8C

D. B. Moore-Shedrow, 773-A

C. D. Strain, 773-A

A. L. Boni, 773-A

A. J. Garrett, 773-A

R. P. Addis, 773-A

E. C. Goodson, DOE 703-46A

J. E. Halverson, 735-A D-Wing

W. A. Emel, 735-A D-Wing

C. H. Hunter, 773-A

R. J. Kurzeja, 773-A

M. J. Parker, 735-7A

J. Stewart, 773-A

A. H. Weber, 773-A

R. Buckley, 773-A

J. T. Hamilton, 735-7A

R. F. Holland, 735-7A

F. A. Cheek, 773-A

A. G. Phillips, 703-43A

W. C. Carlton, 773-A

A. A. Simpkins, 773-A

G. T. Jannik, 773-A

C. E. Murphy, Jr., 773-42A

Ken O'Dell, 773-A

Karen Azzaro, 773-41A

Jean Campbell, 999-W

Brenda Young, 730-B

Bob Lusky, 730-B

Frank Utsch, 773-41A

Jean Mobley (Librarian), SREL 737-A

Jamie Scott, USFS 760-5G

Larry Bryan, SREL 737-A

ATG files, 773-A (4)

Tom Pottberg, Met One Instruments

Matthew Heverly, Met One Instruments

50 extra copies to be delivered to M. J. Parker, 735-7A 


\title{
Westinghouse Savannah River Company
}

\author{
1993 S. Centennial Avenue
}

Aiken, SC 29803

April 1, 1997

Matthew Parker

Building 735-7A

Wcstingliouse Savannah River Company (US Dept. of Energy):

Mel One Instruments has reviewed Matthew J. Parker's $A$ New Wind Vane for the Measuremzent of Amospheric Turbulence ( $U$ ) for the completion of CRADA CR-94-010 and found that it meets the requirements agroed upon. Met One Instruments Inc. gives its approval for the disclosure of CRADA CR-94-010 information in the above mentioned publication in accordance with Article XII of Cooperative Research and Development Agreement CR-94-010.

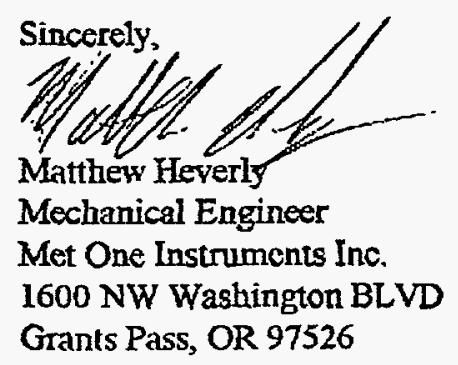




\section{Executive Summary}

A Cooperative Research and Development Agreement (CRADA) between Met One Instruments, Incorporated (Met One) and Westinghouse Savannah River Company (WSRC) was created to develop a new wind vane that more accurately measures atmospheric turbulence. Through a process that had several phases, Met One created a prototype vane that was designed to attach to the existing Model 1585 Bi-Directional Wind Vane instrument structure. The prototype contained over $20 \%$ less mass to enhance responsiveness, which was also increased through the use of a teardrop-shaped fin structure. The prototype vane can be readily manufactured for commercial retail.

Tests in wind tunnel of Building 735-7A, the Meteorological Engineering Facility, indicated that the new vane has a superior starting threshold of less than 0.14 meter per second, a delay distance of 0.72 meter, and a damping ratio of 0.4 . The relative accuracy of less than one degree is unchanged from the previous design. The vane bias was acceptable at 0.8 degree for the horizontal wind angle, but was slightly high at 1.4 degree for the vertical wind angle. The high value of the vertical wind angle bias can most likely be reduced to the desired less than one degree value with standard manufacturing production techniques.

The durability of the prototype vane was not tested in the field but is expected to be slightly less due to the use of hollow rather than foam-filled fins. However, the loss of some durability is more than compensated with increased sensitivity at low wind speeds. Field testing of the prototype is required to test for adequacy of durability. 


\section{List of Figures}

Figure 1. The Met One Model 1585 B-Directional Wind Vane (multiple exposures [left] showing horizontal and vertical motion/still [right] showing instrument with attached vane assembly) 2

Figure 2. Schematic of the top view looking down on the bi-vane mounted inside the wind tunnel at a zero placement and with clockwise and counterclockwise displacements. 5

Figure 3. The Building 735-7A Meteorological Engineering Facility including the wind tunnel 6

Figure 4. Bi-vane with three-dimensional positioner 6

Figure 5. Vane assembly attached to the camshaft 7

Figure 6. The exhaust end of the wind tunnel, with the "one-half" baffle installed, with the "one-third" baffle installed 8

Figure 7. Both the current (bottom) and the prototype vane assembly (top) 9

Figure 8. Relative lengths of the current (bottom) and prototype (top) nose weights 12

Figure 9. Side view of the prototype tear-drop profile (with the end sealed) and the current version 11

\section{List of Tables}

Table 1. Phases of the CRADA 3

Table 2. Specifications of present and proposed bivane 5

Table 3. Relative position accuracies for azimuth and elevation values 10

Table 4. Values of the dynamic bias 12

Table 5. Starting threshold tests 12

Table 6. Values of the damping ratio 13

Table 7. Delay distance values 14

Table 8. Goals versus actual specifications of the final prototype 15 


\section{Contents}

\section{Executive Summary 1}

Introduction 2

The Model 1585 Bi-Directional Vane (Bivane) 3

Theory and Tests of Vane Performance 3

Relative Accuracy 3

Dynamic Vane Bias 4

Starting Threshold 4

Damping Ratio 4

Delay Distance 4

The 735-7A Wind Tunnel 4

Phase 1 Meeting 5

The 735-7A Wind Tunnel and the Development of Low-Speed

Filters 7

Final Prototype Test Results 7

Tail Balance and Relative Position Accuracy 10

Dynamic Vane Bias 10

Starting Threshold 10

Damping Ratio 13

Delay Distance 13

Comparison to Goals and Conclusions 14

Acknowledgments 15

References 15 


\title{
A New Wind Vane for the Measurement of Atmospheric Turbulence(U)
}

\author{
M. J. Parker
}

Westinghouse Savannah River Company

M. Heverly

Met One Instruments, Incorporated

Prepared for the U.S. Department of Energy under contract no. DE-AC09-89SR18035 

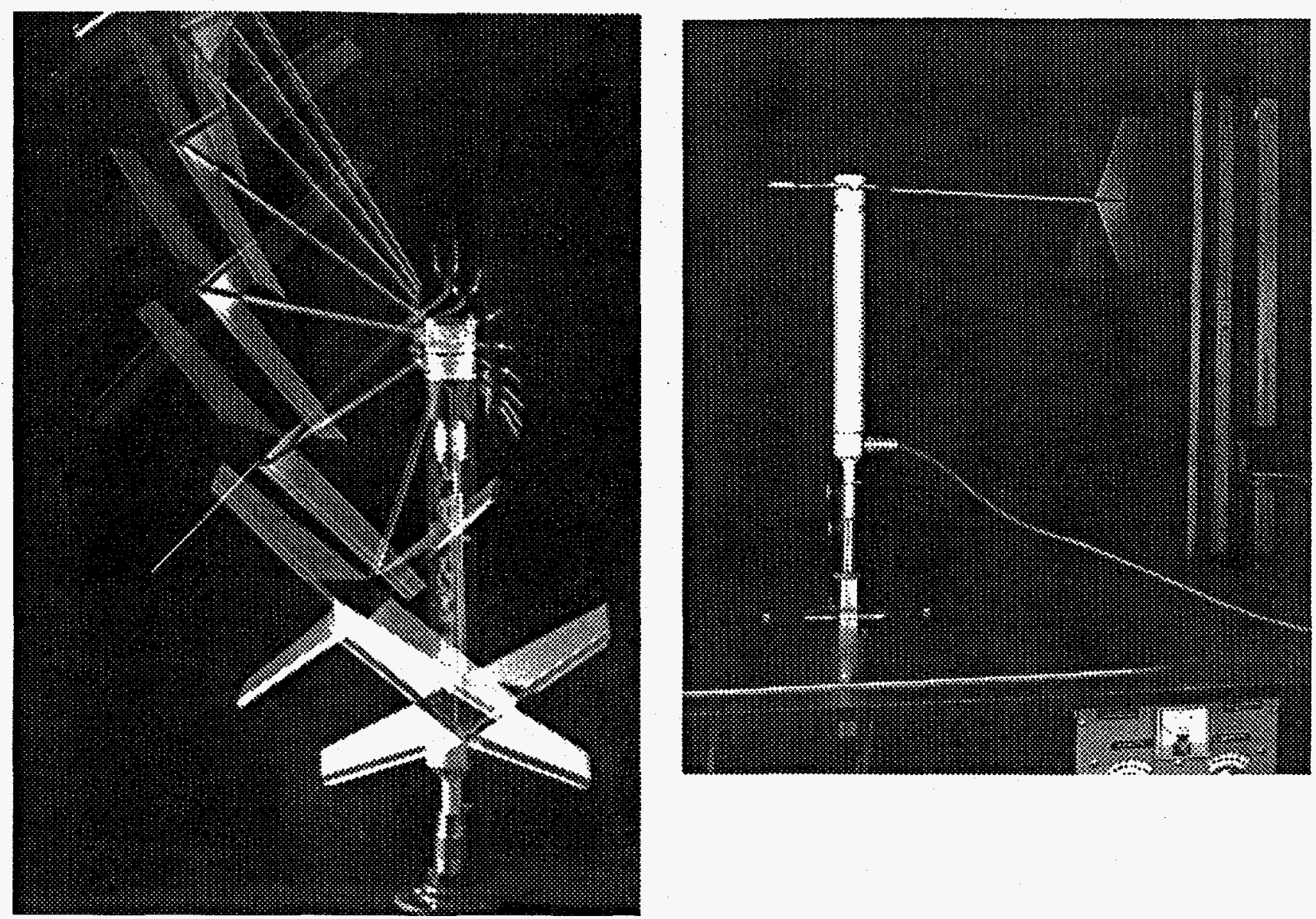

Figure 1. The Met One Model 1585 B-Directional Wind Vane (multiple exposures [left] showing horizontal and vertical motion/still [right] showing instrument with attached vane assembly)

\section{Introduction}

A Cooperative Research and Development Agreement (CRADA) between Met One Instruments, Incorporated (Met One) and Westinghouse Savannah River Company (WSRC) (CRADA CR-94-010) to develop an improved wind vane for measuring atmospheric turbulence was formalized on September 21, 1994. The initial discussions about creating a joint effort to improve the performance of the Model 1585 Bi-Directional Wind Vane (bivane), which is used extensively in the meteorological monitoring program at the Savannah River Site (Parker and Addis 1993), occurred with the previous manufacturer of the bivane, Teledyne Geotech. In the early 1990s, Met One purchased the meteorological instrumentation product line from Teledyne Geotech including the bivane. Mct One also retained some of the Teledyne Geotech personnel who were involved with the development of the CRADA. The Principal Investigator (PI) for WSRC was Matthew J. Parker and, initially, Tom Pottberg, President of Met One. Dennis Recla and finally, Matthew Heverly of Met One were the second and third PIs for Met One. The need to change PIs by Met One was due primarily to shifting work loads during a period of rapid growth.

The CRADA was designed to follow a path forward covering 16 months. During Phase 1, WSRC personnel met with Met One at their headquarters/manufacturing plant in Grants Pass, Oregon, to discuss proposed vane performance specifications. In Phase 2, Met One was to build a single-axis vane prototype that WSRC would test in the 735-7A wind tunnel in Phase 3. Phases 4 and 5 were analogous to steps 2 and 3 in that Met One would develop a bivane prototype for more wind tunnel tests to be performed by WSRC. Phase 6 was the documentation of the final results of the CRADA. Met One modified this plan and decided to design a final prototype bivane design. In dealing with the costs of the CRADA, Met One decided that significant costs could be avoided by limiting the need for expensive die-casts for both a single-axis wind vane and bivane. Therefore, Met One concentrated on the development of a bivane prototype. WSRC tested the final prototype in the 735-7A wind tunnel facility. An extension of this plan to a September 21, 1996 completion date 
was approved in February 1996. Table 1 summarizes all of the proposed and actual phases that occurred as part of this CRADA.

Table 1. Phases of the CRADA.

\begin{tabular}{l|l}
\hline \multicolumn{2}{l}{ Proposed Phases } \\
\hline Phase 1 & $\begin{array}{l}\text { Meeting between Met One and } \\
\text { WSRC in Grants Pass, Oregon. }\end{array}$ \\
\hline Phase 2 & Met One builds single-axis prototype. \\
\hline Phase 3 & $\begin{array}{l}\text { WSRC tests single-axis prototype } \\
\text { in 735-7A wind tunnel. }\end{array}$ \\
\hline Phase 4 & Met One builds dual-axis prototype. \\
\hline Phase 5 & $\begin{array}{l}\text { WSRC tests dual-axis prototype } \\
\text { in 735-7A wind tunnel. }\end{array}$ \\
\hline Phase 6 & Documentation of final results \\
\hline & \multicolumn{1}{|c}{ Actual Phases } \\
\hline Phase 1 & $\begin{array}{l}\text { Meeting between Met One and } \\
\text { WSRC in Grants Pass, Oregon. }\end{array}$ \\
\hline Phase 2 & $\begin{array}{l}\text { Met One builds final-dual axis } \\
\text { prototype. }\end{array}$ \\
\hline Phase 3 & $\begin{array}{l}\text { WSRC tests dual-axis prototype in } \\
735-7 A \text { wind tunnel. }\end{array}$ \\
\hline Phase 4 & Documentation of final results. \\
\hline
\end{tabular}

\section{The Model 1585 Bi-Directional Vane (Bivane)}

The Model 1585 Bi-directional Wind Vane or bivane (Figure 1) is used to measure horizontal and vertical wind direction simultaneously. A crossed, double-fin vane assembly is attached to the side of the insirument onto an exterior extension shaft with a hub assembly and setscrew. The exterior shaft extends through a camshaft inside the head of the instrument, and this cam, by its design, automatically keeps the vane assembly horizontal. The camshaft acts as a self-leveling mechanism for the vane assembly to deflections in the vertical plane. Horizontal wind measurements are taken with a resolver technique that compares a standing square wave voltage with a similar moving output voltage from the vane's location. By comparing the two voltages, the horizontal wind direction can be resolved to a final accuracy of two degrees with a resolution of around 0.07 degree. The vertical wind direc- tion is determined with an inductance method which locates the vane shaft via the position of the self-leveling camshaft. The induced-electrical field is converted to a degree measure corresponding to the location of the vane assembly. The accuracy for the vertical wind direction is two degrees with a resolution of 0.024 degree.

Output voltages from the bivane are converted to a 0 to 5 volt scale with signal processing circuit cards. Engineering units in degrees are calculated from the output voltages. The conversion factor for the horizontal wind direction is 0.0138 volt per degree and 0.0416 volt per degree for the vertical wind direction. There is a one-degree gap in the horizontal wind direction from 359.5 degrees to 0.5 degrees.

\section{Theory and Tests of Vane Performance}

Theoretical research of wind vanes has been conducted with tests designed to quantify the performance of a vane under controlled conditions (MacCready and Jex 1964; Wieringa 1967; Wieringa and van Lindert 1970; Finkelstein 1981). These controlled conditions can be produced in a wind tunnel of sufficient size to allow a smooth, unobstructed air flow that can act on a wind vane without regard to boundary effects of the tunnel itself. In essence, a test section with a stable platform and variable air flow control capability will suffice as long as approximately only $5 \%$ or less of the test section is occupied by the sensor during testing (ASTM 1995). The "smoothness" of the air in the test section will be maximized through the design of the tunnel and by a filter system, which limits the size of turbulent eddies entering the tunnel. (The WSRC wind tunnel is described later in this document.)

Different vane designs have been tested to determine the preferable style to optimize performance and accuracy. As a means of test standardization, several specific performance tests have been developed (ASTM 1995) to allow intercomparison of vane types and to provide guidance for selecting proper wind vanes for an application such as monitoring at nuclear facilities or air pollution stations. A description of the tests used in this CRADA are addressed in the paragraphs that follow.

\section{Relative Accuracy}

Relative accuracy is determined through the use of a test fixture which allows a comparison of the measured output of the wind vane to a geometrically designed apparatus temporarily attached to the vane (EPA 1995). The voltage output for a 0 to 5 volt range over 360 degrees is 0.01388 volt per degree. Expected values are compared to expected 
calculated values. A typical high-quality wind vane should measure horizontal degree values to a 2 or 3 degree accuracy at 30 degree intervals. An output voltage gap of up to 5 degrees at 0 degrees is common, but otherwise, the voltage output is expected to be linear in nature.

\section{Dynamic Vane Bias}

The dynamic vane bias is a test of the ability of the vane to align with the flow of the wind tunnel (ASTM 1995). The dynamic vane bias is tested by comparing the output of the wind vane at the tunnel centerline without air flow and the output of the wind vane when the air flow in the tunnel is set to a nominal rate of, say, 5 meters per second. In general, the wind vane should show an error of one degree or less.

\section{Starting Threshold}

The starting threshold of a wind vane is defined as the lowest wind-speed necessary to move a wind vane at least one degree from an offset angle of ten degrees (ASTM 1995). Typically, the starting threshold is tested by resting the vane at a ten-degree angle to the flow centerline of the wind tunnel and increasing air flow until the required response is observed. Careful consideration must be given to ensure that the vane is not influenced by any force other than a steady, non-accelerating air flow. The starting threshold is mainly influenced by the configuration of the wind vane and its attachment to the instrument body, which induces opposing forces such as those caused by bearings at the attachment point.

\section{Damping Ratio}

The damping ratio is a measure of a vane's ability to respond to a step function change in wind direction (ASTM 1995). Calculations of the "unitless" damping ratio allow intercomparison of vane types and styles. In general, the damping ratio should be 0.4 or greater for wind direction sensors used to provide data for calculations of atmospheric dispersion.

To measure the damping ratio, the vane is held at a tendegree offset angle and released. Three key measurements are made during the testing process; release point, maximum displacement, and final vane location resulting from the tunnel air flow alone. The equations below are used to calculate the damping ratio, $\eta$.

$$
\eta=\frac{\ln (1 / \Omega)}{\left(\pi^{2}+\ln [1 / \Omega]^{2}\right)^{0.5}}
$$

where $\Omega$ is the overshoot ratio,

$$
\Omega=\Theta_{(\mathbf{n}+1)} / \Theta_{n}
$$

and $\Theta_{n}$ and $\Theta_{n+1}$ are the $n$ and $n+1$ overshoots, respectively (ASTM 1995).

Tests are made at 5 and 10 meters per second. The average of five clockwise releases are combined with the average of five counterclockwise releases (Figure 2) to calculate the damping ratio at a given wind speed.

Tests of the vertical wind damping ratio are invalid for the Model 1585 bivane since a self-leveling cam is used to maintain the vane at zero degrees elevation angle. Therefore, the vane does not respond exclusively to the air flow during the adjustment to the step-function change in wind direction.

\section{Delay Distance}

The delay distance is the length of an air column passing by a vane as the vane responds to $50 \%$ of an initial 10 degree offset angle (ASTM 1995). The delay distance can be determined by multiplying the time required to make the $50 \%$ response by the speed of the air flowing past the vane during that time. Measurements of the delay distance are made in the same manner as those for the damping ratio except that only the $50 \%$ displacement, time, and wind speed are measured.

\section{The 735-7A Wind Tunnel}

Personnel at WSRC operate an Aerolab subsonic wind tunnel in the 735-7A Meteorological Engineering Facility (Figure 3). The tunnel functions by drawing air through the tunnel structure with a motorized fan. The air enters the wind tunnel through a honeycomb filter, which limits the size of turbulent eddies entering the tunnel. After passing through the filter, air continues through a section of areal reduction to the test section of the wind tunnel. The air flow rate through the test section is readily controlled by regulating the rate of rotation of the fan blades. Turbulent eddies are virtually non-existent in the test section, which creates an ideal testing platform inside the wind tunnel. Air flow can be regulated from approximately 0.5 to 23 meters per second. Calibrations are made with standards traceable to National Institute for Standards and Testing (NIST).

A three-dimensional positioning arm (Figure 4) is used as a release mechanism in the rear of the tunnel test section. Repeatability of the positioner can be easily accomplished to one-tenth of one horizontal degree. The release mechanism does not impart any additional force to the vane upon release. 
Data acquisition is performed with Labtech Notebook $\$$ on a personal computer. Data sampling rates can be varied, but 200 hertz was commonly used for all wind tunnel tests. Data storage files were made in the random access memory to enhance data sampling rates, and permanent files were stored onto the hard drive of the personal computer. Data analyses were conducted after the data were stored.

\section{Phase 1 Meeting}

In Phase 1, a meeting to discuss possible prototype vane designs for single-axis and dual axis wind vanes was completed at Met One's facilities on November 15, 1994. In attendance were Tom Pottberg, Wallace Wilson, Dennis Recla, and other Met One staff members, as well as Dr. Tom Lockhart of the Meteorological Standards Institute and Matthew J. Parker of WSRC. Matthew Heverly of Met One had not been hired by Met One as of this date.

The consensus among meeting members was that the performance of any prototype should be improved for better response at low-wind speeds without sacrificing overall performance. The actual part of the bivane to be modified was determined to be the vane assembly, which attaches to a camshaft on the Model 1585 bivane instrument (Figure 5). The new vane assembly must also be compatible to the Model 1585 bivane. Therefore, the following specifications for the final prototype vane were developed:

- damping ratio of 0.45 or greater

- starting threshold of 0.25 meter per second or less

- a delay distance of 0.7 meter or less

Top View of Bivane Mounted Inside Wind Tunnel

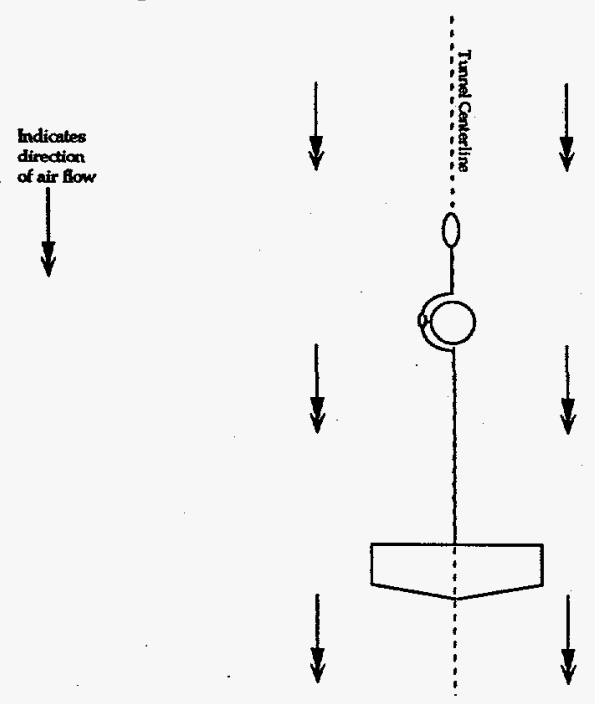

All other relevant specifications, such as accuracy, for the Model 1585 Bivane were acceptable and were to be maintained. Additional consideration to durability at high-wind speeds (33 meters per second) and possibly precipitation shedding were determined to be desirable. Dr. Lockhart suggested that a front dampening "fin" or plate on the vane assembly would increase the vane's ability to conform to step-function changes in air flow or damping ratio. Table 2 summarizes the specifications for the existing and prototype vanes for the Model 1585.

Table 2. Specifications of present and proposed bivane

\begin{tabular}{l|c|c}
\hline \multicolumn{1}{c|}{ Specification } & Present & Proposed \\
\hline Damping ratio & 0.4 & 0.45 \\
\hline Starting threshold & $0.5(\mathrm{~m} / \mathrm{s})$ & $0.25(\mathrm{~m} / \mathrm{s})$ \\
\hline Delay distance & $1.0 \mathrm{~m}$ nominal & $0.7 \mathrm{~m}$ \\
\hline $\begin{array}{l}\text { Accuracy (horizontal } \\
\text { and vertical) }\end{array}$ & \pm 2 degrees & \pm 2 degrees \\
\hline $\begin{array}{l}\text { Resolution (horizon- } \\
\text { tal) }\end{array}$ & 0.072 degree & $\begin{array}{c}0.072 \\
\text { degree }\end{array}$ \\
\hline Resolution (vertical) & 0.024 degree & $\begin{array}{c}0.024 \\
\text { degree }\end{array}$ \\
\hline Range horizontal & $0-360$ degrees & $\begin{array}{c}0-360 \\
\text { degrees }\end{array}$ \\
\hline Range vertical & -60 to +60 & $\begin{array}{c}-60 \text { to }+60 \\
\text { degrees }\end{array}$ \\
\hline
\end{tabular}

- Top View of Bivane Mounted Inside Wind Tunnel with Release Orientations

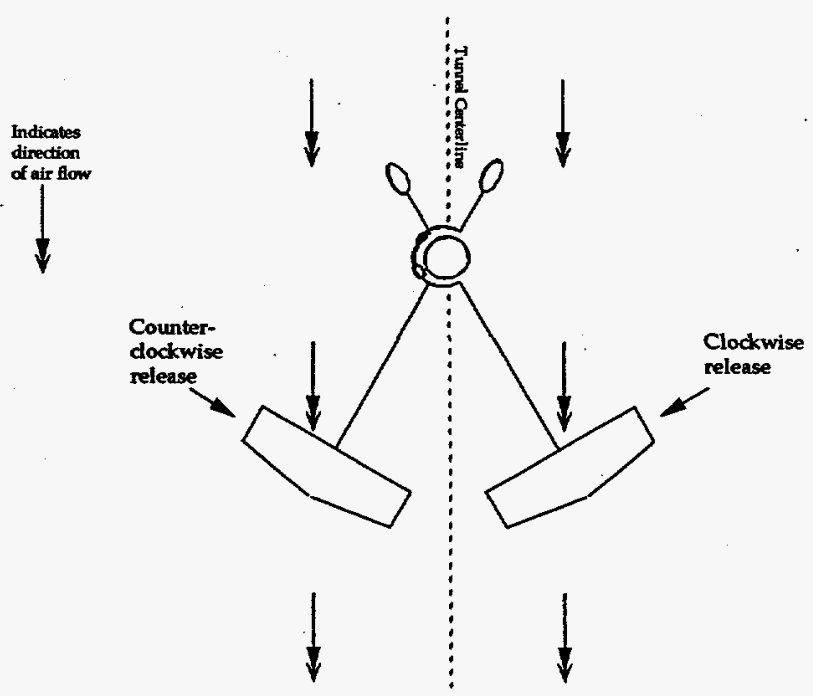

Figure 2. Schematic of the top view looking down on the bi-vane mounted inside the wind tunnel at a zero placement and with clockwise and counterclockwise displacements. 


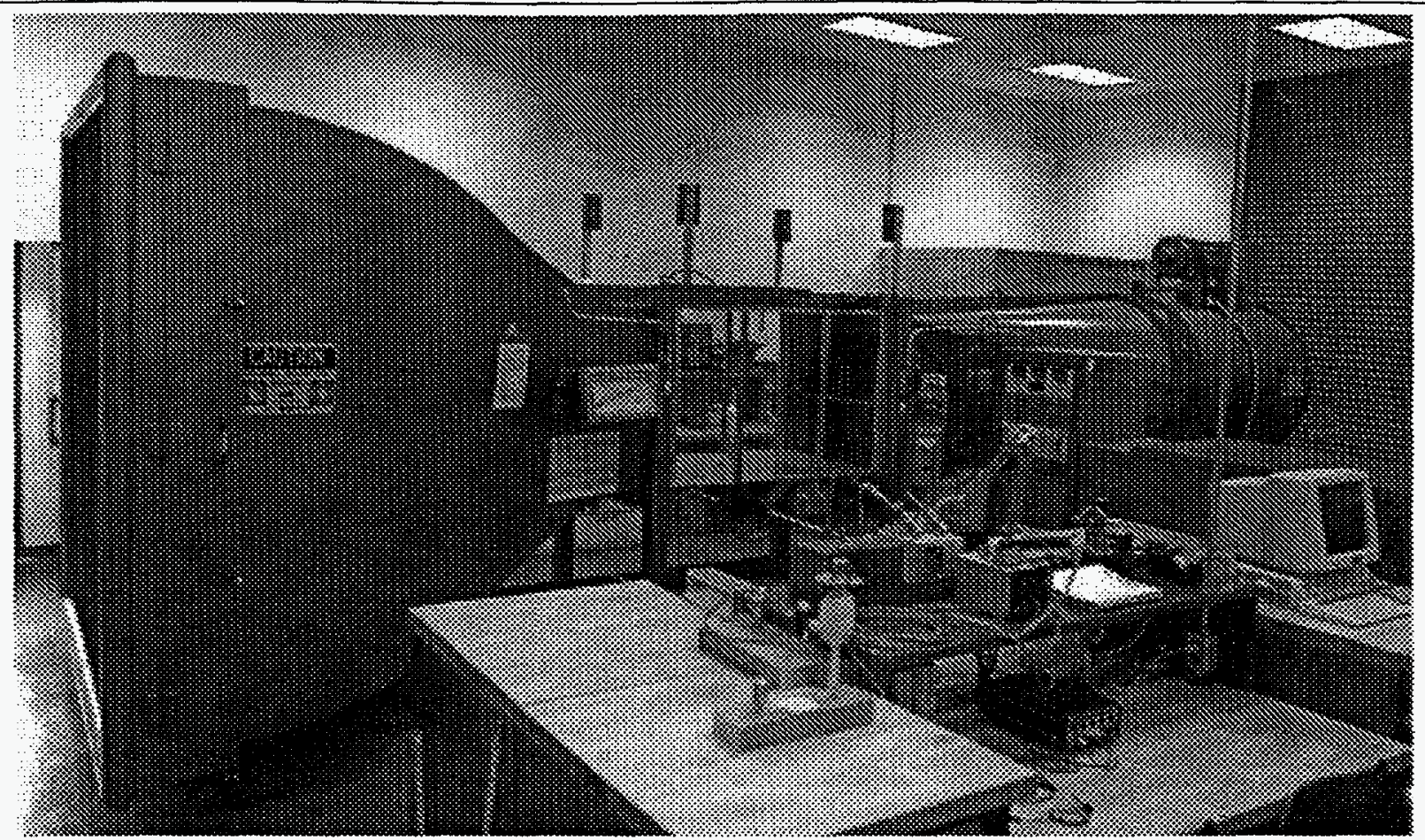

Figure 3. The Building 735-7A Meteorological Engineering Facility including the wind tunnel

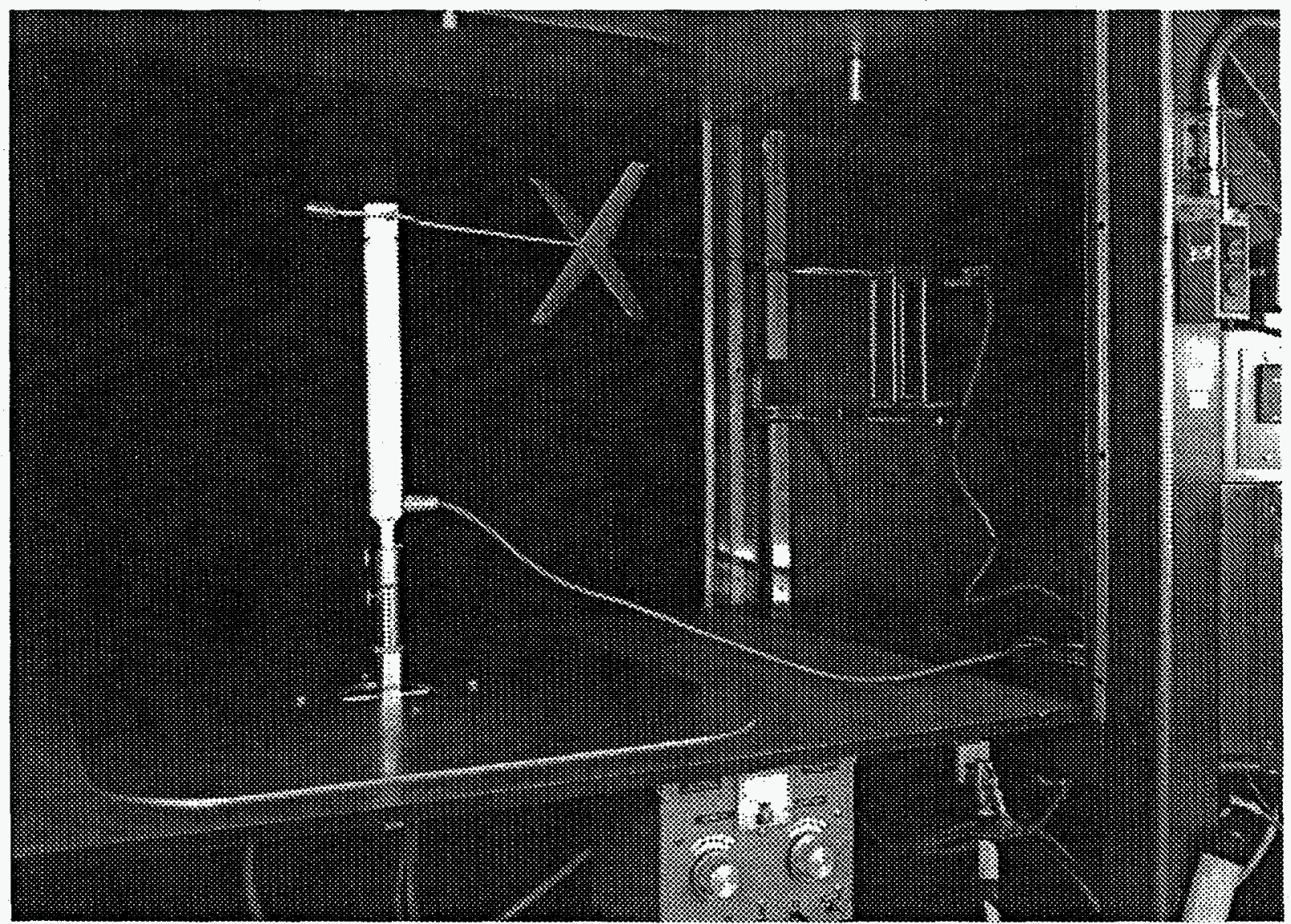

Figure 4. Bi-vane with three-dimensional positioner 


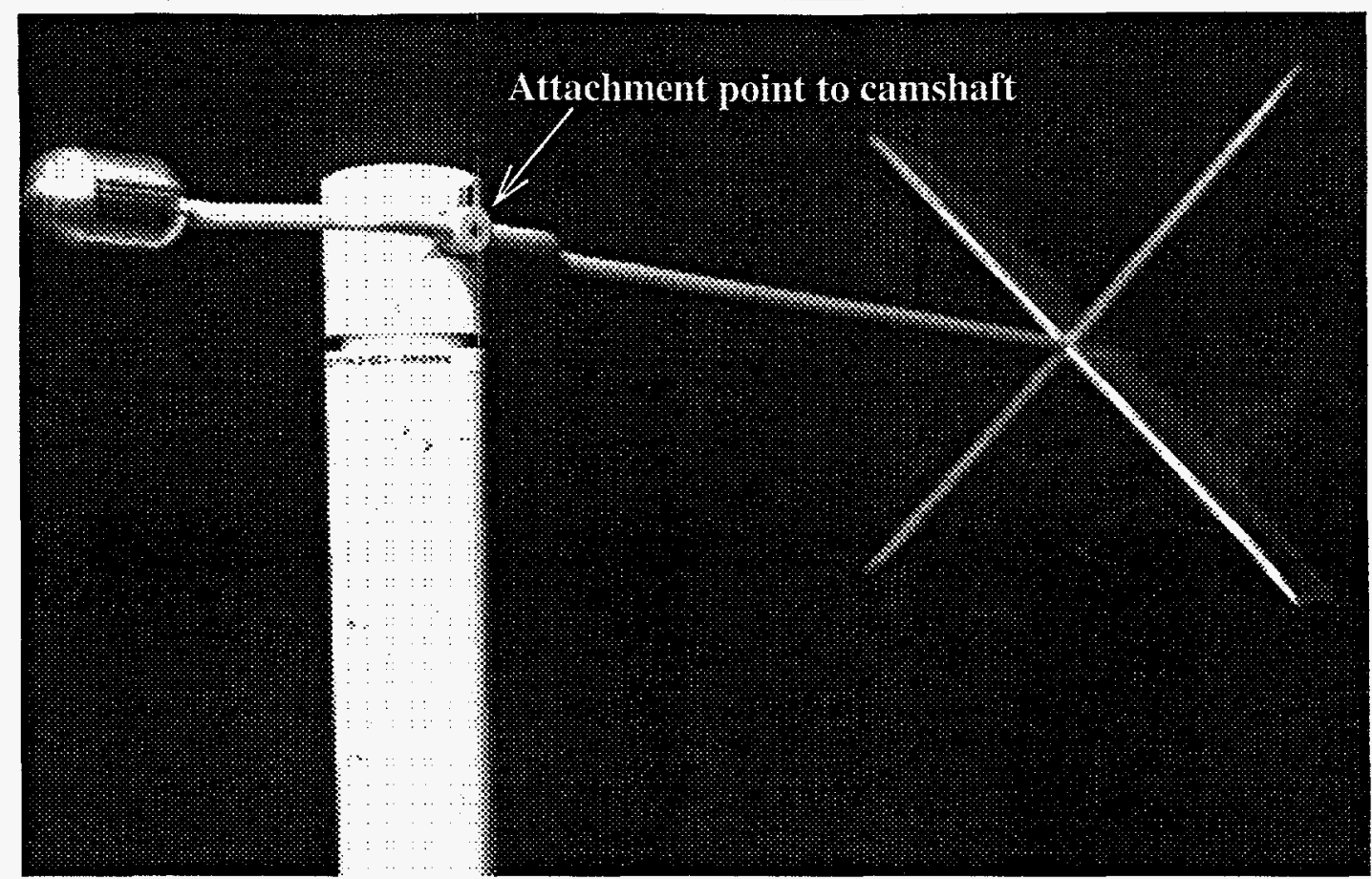

Figure 5. Vane assembly attached to the camshaft

\section{The 735-7A Wind Tunnel and the Development of Low-Speed Filters}

The lowest air flow rate commonly used for testing meteorological instrument starting thresholds is near 0.5 meter per second, but as stated in the specifications in Phase 1, the low wind speed tolerance for the prototype was 0.25 meter per second. Therefore, an adjustment to the 735-7A wind tunnel became necessary to conduct starting threshold measurements.

After consulting with the manufacturer of the wind tunnel, Aerolab, it was decided that the sirnplest and most cost-effective method of lowering the low end air flow rates would be to restrict the amount of air passing through the exhaust end of the tunnel. A baffle that restricts the flow by one-half was designed and built. Tests with a gill-propeller anemometer indicate that the flow was reduced from 0.53 meter per second without the baffle to 0.26 meter per second with the baffle installed. $A$ second flow restriction device that fits over the baffle can reduce the flow to one-third of the original flow rate (Figure 6). Tests indicate that the flow can be reduced to less than 0.15 meter per second with the additional restriction plate and the tunnel control motor adjusted to the lowest possible setting. Both of the restriction devices can be installed or removed in a matter of minutes.

\section{Final Prototype Test Results}

Met One created a final vane assembly prototype that is compatible with the Model 1585 bivane. The vane was built by hand and is remarkably similar to the present commercial version with some key differences (Figure 7). The shape of the vane fins resembles a teardrop in profile rather than the more square edges of the original version (Figure 8). The mass of the vane assembly was reduced by $26.3 \%$ from 190.0 grams to 140.0 grams by removing the foam inserts inside of the vane fins. The mass of the counterweight was reduced by $21.3 \%$ from 150.0 grams to 118.0 grams. The idea of reducing the mass of the vane assembly was determined to be critical based on tests of an ad hoc prototype (not shown) that was made of lightweight components and was more responsive. The entire length of the vane assembly remained unchanged at 38.4 centimeters, but the length of the counterweight was reduced from 4.7 centimeters to 2.4 centimeters (Figure 9).

By reducing the mass of the vane assembly and counterweight and changing the shape of the fins to that of a teardrop, Met One intended the prototype to be more responsive to low-wind speeds and to increase the damping ratio. Preliminary wind tunnel tests of the vane's performance were conducted by Met One at their Rowlett, Texas facility with acceptable results. More detailed tests were conducted in June and July 1996 at the WSRC wind tunnel test facility after the prototype was shipped from Rowlett to the Savannah River Site. The results of these tests are described below. 

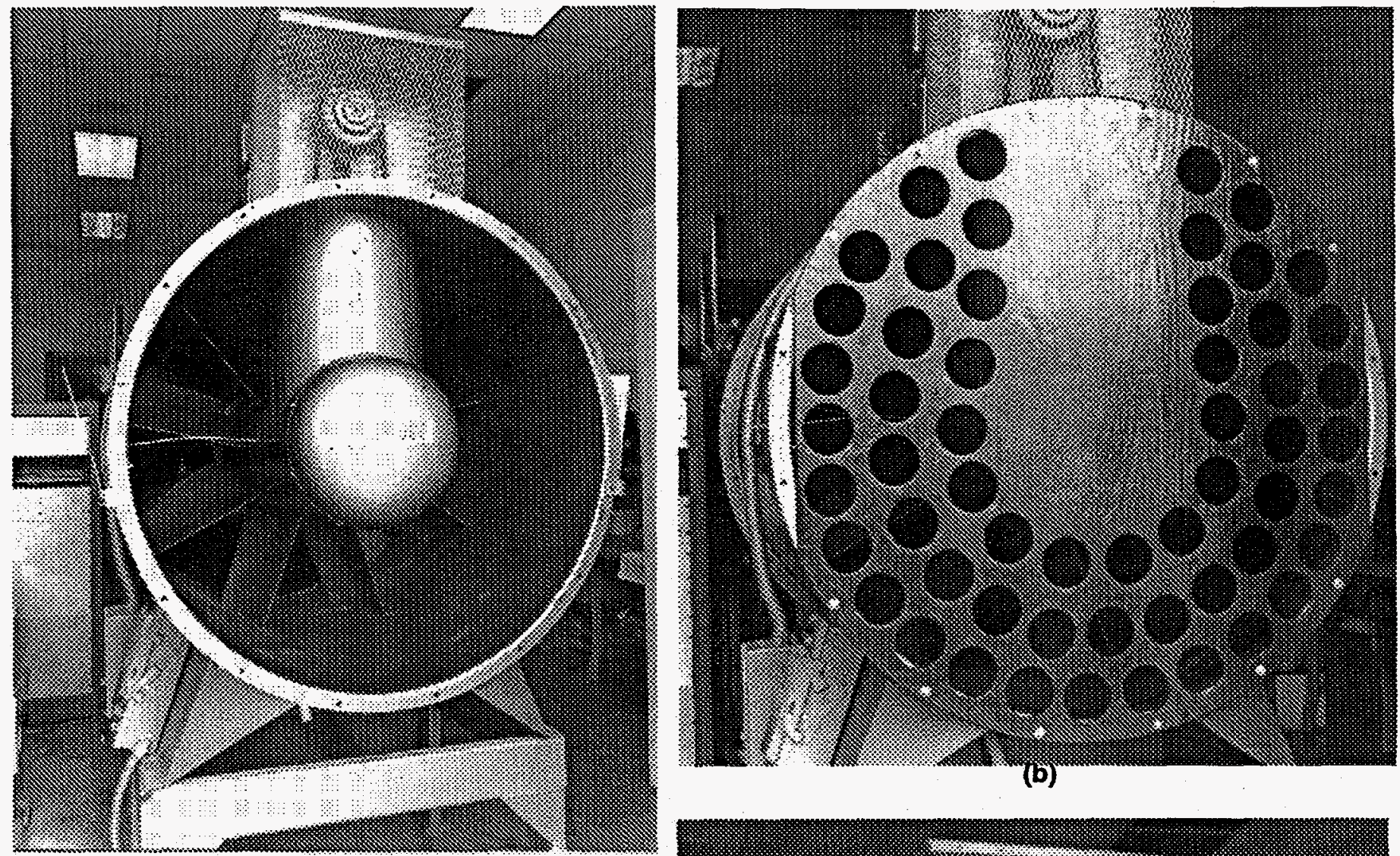

(b)

(a)

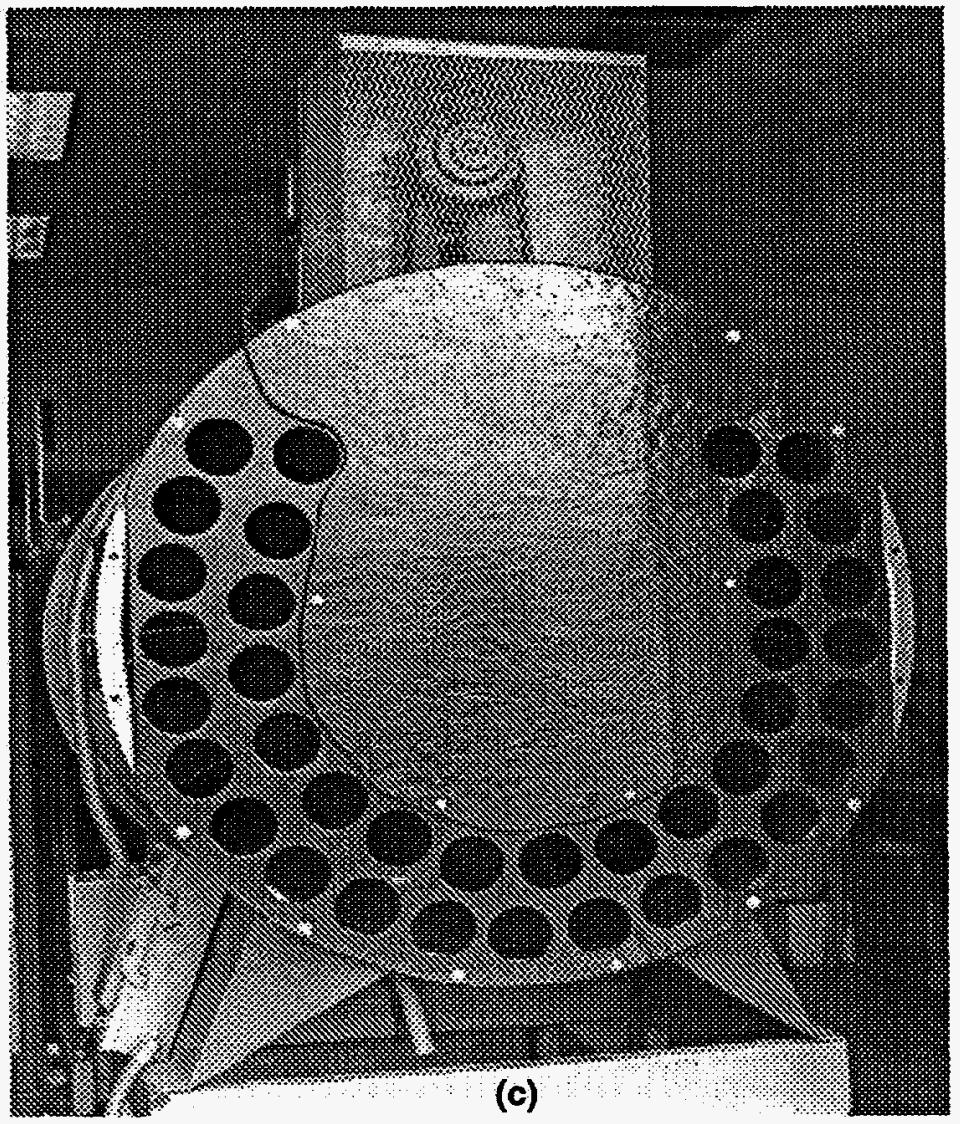

Figure 6. The exhaust end of the wind tunnel (a), with the "one-half" baffle installed (b), and with the "one-third" baffle installed (c) 


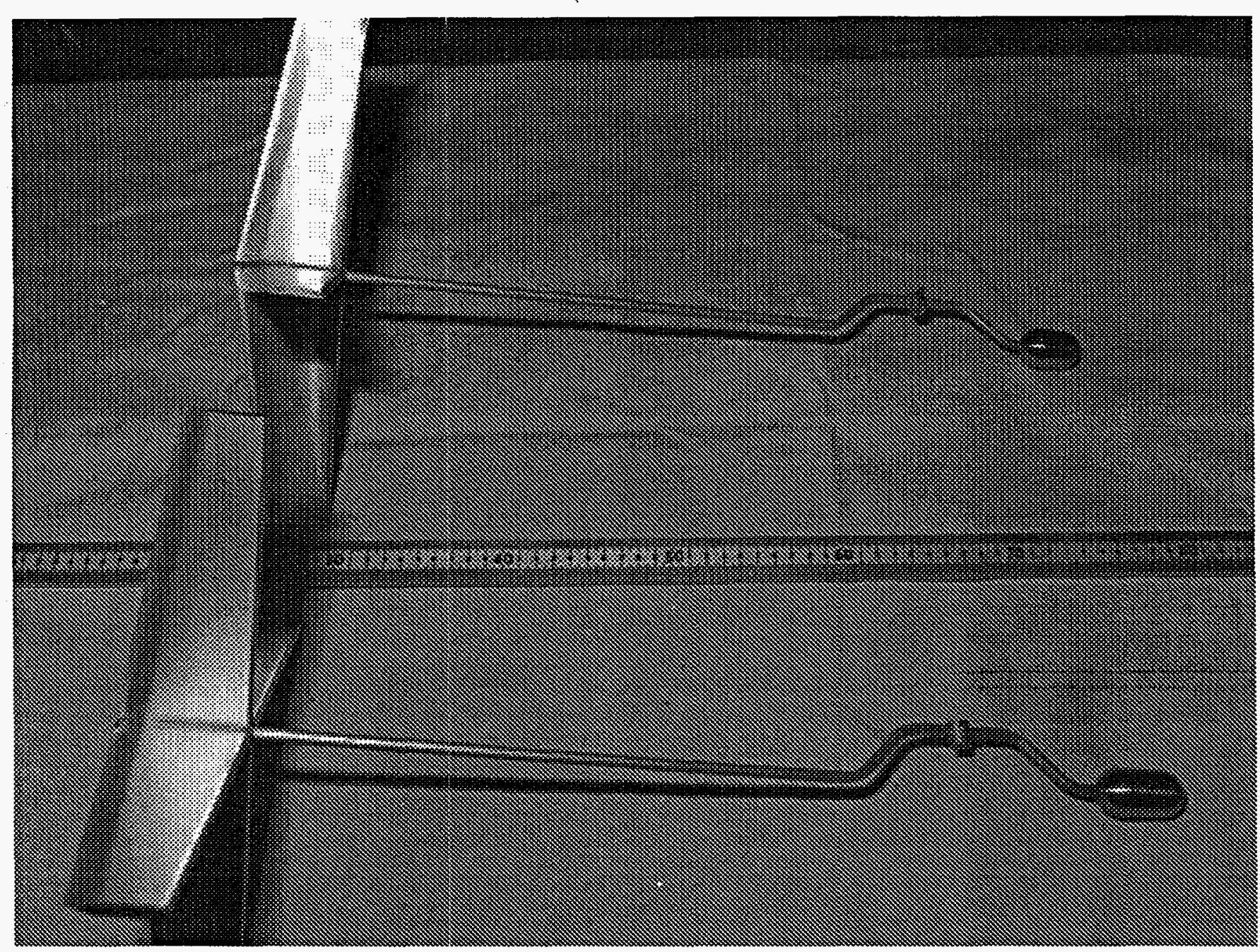

Figure 7. Both the current (bottom) and the prototype vane assembly (top) 


\section{Tail Balance and Relative Position Accuracy}

The prototype vane assembly was carefully crafted by hand. This carefulness was evident in the ease of maintaining a balanced vane after installation. Tests of the relative position accuracy (Table 3 ) indicated that the average azimuthal error was 0.32 degree and the average vertical error was 0.82 degree. These errors are relatively unaffected by the prototype vane since the identical Model 1585 bivane shaft is used on the prototype. Measurements of the relative accuracy are made by orienting this shaft in a test fixture.

\section{Dynamic Vane Bias}

Measurements of the dynamic vane bias for the azimuth and elevation functions were made at 5 meters per second. As stated previously, the dynamic vane bias should be less than one degree. Tests results are shown in Table 4. The bias for the azimuth was 0.8 degree which is acceptable. The bias for the elevation was somewhat higher at 1.4 degrees. The larger magnitude of the elevation bias was due to the fins being slightly offcenter, which is common for hand-built prototypes. It is likely that more elaborate machining would alleviate the dynamic vane bias in the vertical direction function

\section{Starting Threshold}

The starting threshold of the prototype vane assembly was measured in the 735-7A wind tunnel with flow restricting filters installed. Typical starting threshold values for commercial wind vanes are 0.5 meter per second or less. The prototype vane assembly responded to air flow rates of less than 0.14 meter per second! This indicates a very high level of responsiveness which implies exceptional operation even under nearly calm wind conditions. The true starting threshold is below the lowest operating limits of the 735-7A wind tunnel, however, since the vane assembly responded by aligning itself with the tunnel centerline or over 10 degrees, the actual true starting threshold is likely significantly below 0.14 meter per second. Table 5 summarizes the results of the starting threshold tests.
Table 3. Relative position accuracies for azimuth and elevation values

\begin{tabular}{|c|c|c|c|c|}
\hline Angle & $\begin{array}{c}\text { Ex- } \\
\text { pected }\end{array}$ & Actual & $\begin{array}{c}\text { Ab- } \\
\text { solute } \\
\text { Error }\end{array}$ & \\
\hline (deg) & (volt) & (volt) & (deg) & \\
\hline 0 & 0.000 & 4.998 & -0.14 & \\
\hline 30 & 0.417 & 0.411 & 0.43 & \\
\hline 60 & 0.833 & 0.823 & 0.72 & \\
\hline 90 & 1.250 & 1.244 & 0.43 & \\
\hline 120 & 1.667 & 1.672 & -0.36 & \\
\hline 150 & 2.083 & 2.090 & -0.50 & $\begin{array}{l}\text { Average error: } \\
0.32 \text { degree }\end{array}$ \\
\hline 180 & 2.500 & 2.500 & 0.00 & (absolute) \\
\hline 210 & 2.917 & 2.918 & 0.14 & \\
\hline 240 & 3.333 & 3.328 & 0.36 & \\
\hline 270 & 3.750 & 3.747 & 0.22 & \\
\hline 300 & 4.167 & 4.171 & -0.29 & \\
\hline 330 & 4.583 & 4.586 & -0.22 & \\
\hline $\begin{array}{l}\text { Angle } \\
\text { (deg) }\end{array}$ & $\begin{array}{l}\text { Expected } \\
\text { (volt) }\end{array}$ & $\begin{array}{l}\text { Actual } \\
\text { (volt) }\end{array}$ & $\begin{array}{l}\text { Error } \\
(\text { deg) }\end{array}$ & \\
\hline 0 & 2.500 & 2.499 & 0.024 & \\
\hline 10 & 2.917 & 2.932 & -0.36 & \\
\hline 20 & 3.333 & 3.362 & -0.70 & \\
\hline 30 & 3.750 & 3.784 & -0.82 & \\
\hline 40 & 4.167 & 4.202 & -0.84 & $\begin{array}{l}\text { Average error: } \\
0.82 \text { degree }\end{array}$ \\
\hline 50 & 4.583 & 4.619 & -0.86 & (absolute) \\
\hline-10 & 2.083 & 2.054 & 0.70 & \\
\hline-20 & 1.667 & 1.630 & 1.61 & \\
\hline-30 & 1.250 & 1.210 & 0.96 & \\
\hline-40 & 0.833 & 0.800 & 0.79 & \\
\hline-50 & 0.417 & 0.362 & 1.32 & \\
\hline
\end{tabular}




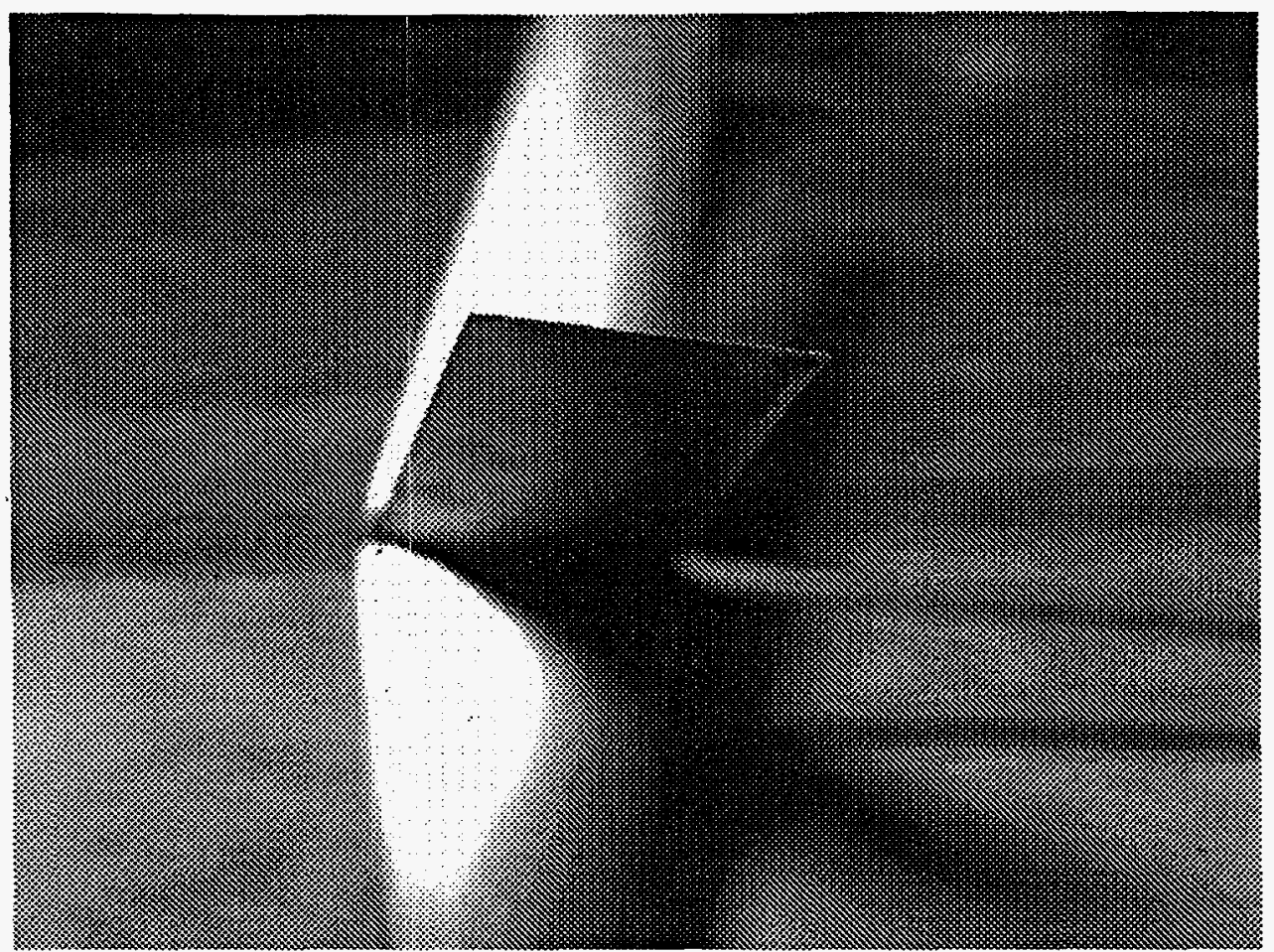

(prototype)

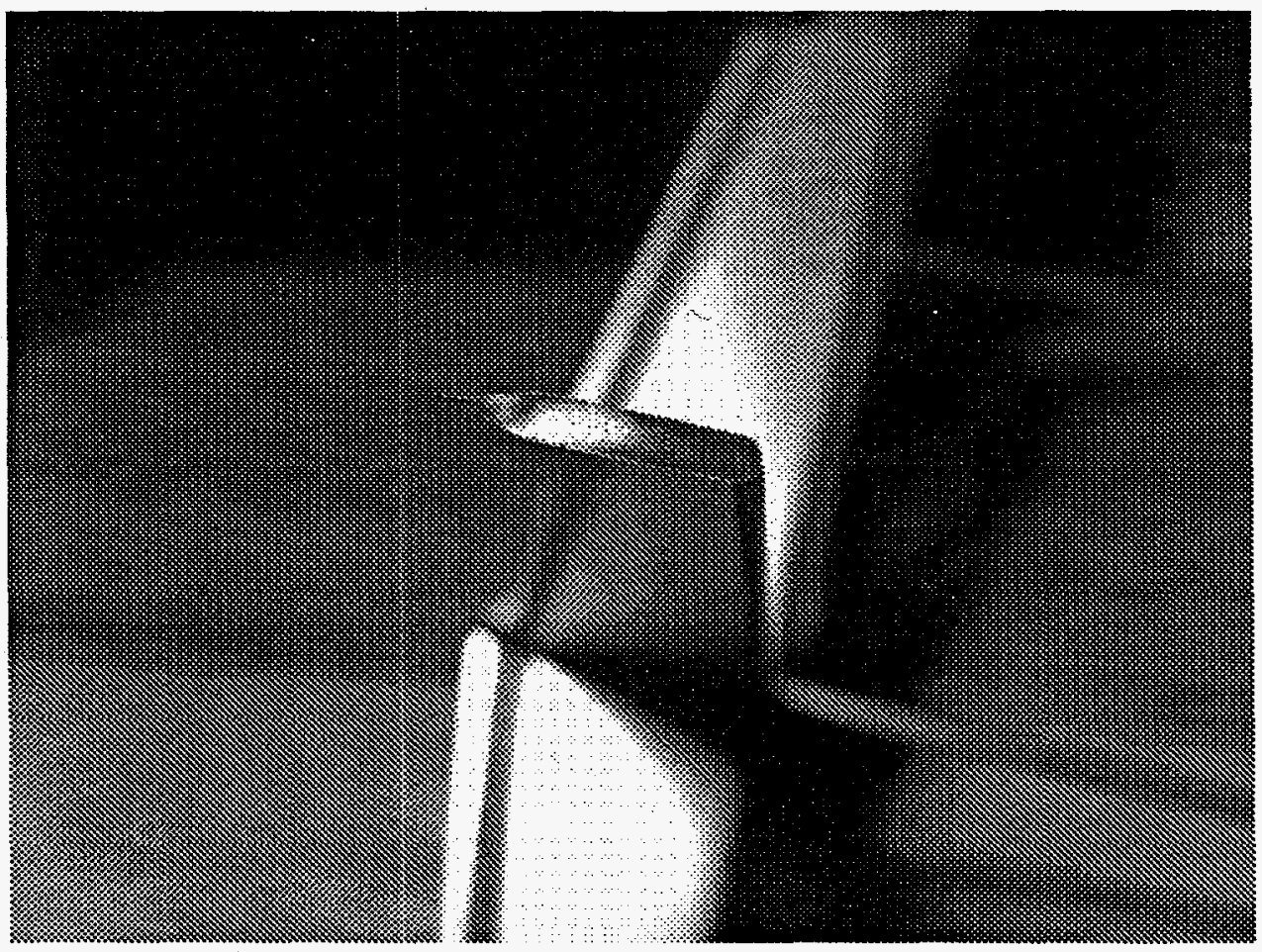

(present version)

Figure 8. Side view of the prototype tear-drop profile (with the end sealed) and the current version 


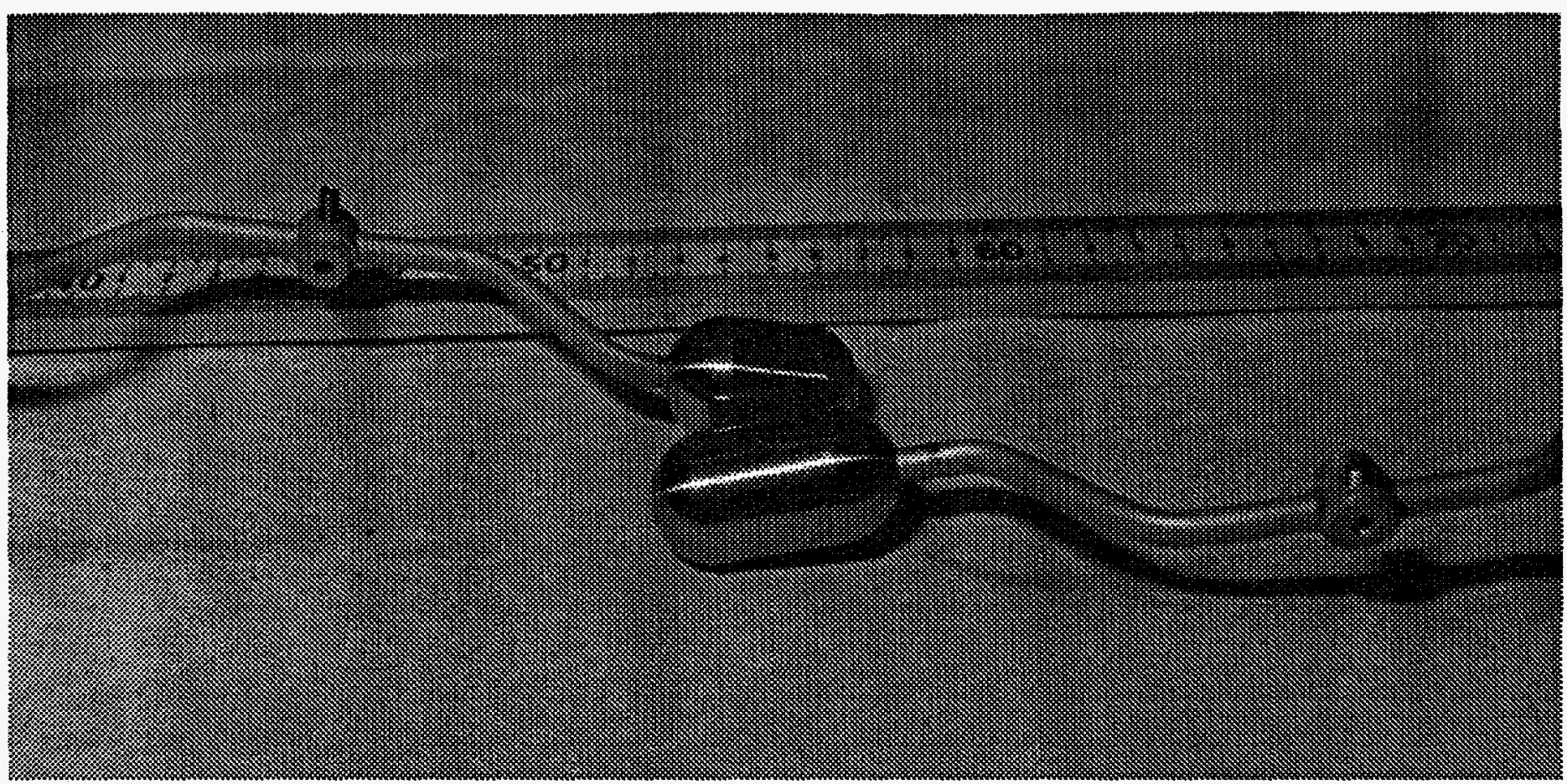

Figure 9. Relative lengths of the current (bottom) and prototype (top) nose weights

Table 4. Values of the dynamic bias

\begin{tabular}{|c|c|c|c|}
\hline $\begin{array}{l}\text { Azimuth } \\
\text { (horizontal) }\end{array}$ & & & \\
\hline $\begin{array}{l}\text { Tunnel speed } \\
(\mathrm{m} / \mathrm{s})\end{array}$ & $\begin{array}{l}\text { Azimuth } \\
\text { (volt) }\end{array}$ & & $\begin{array}{l}\text { Azimuth } \\
\text { (degrees) }\end{array}$ \\
\hline 0 & 2.450 & & 176.4 \\
\hline \multirow[t]{2}{*}{5} & 2.461 & & 177.2 \\
\hline & & Bias & 0.8 \\
\hline \multicolumn{4}{|l|}{$\begin{array}{l}\text { Elevation } \\
\text { (vertical) }\end{array}$} \\
\hline $\begin{array}{l}\text { Tunnel speed } \\
(\mathrm{m} / \mathrm{s})\end{array}$ & $\begin{array}{l}\text { Eleva- } \\
\text { tion } \\
\text { (volt) }\end{array}$ & & $\begin{array}{l}\text { Elevation } \\
\text { (degrees) }\end{array}$ \\
\hline 0 & 2.563 & & 1.5 \\
\hline \multirow[t]{2}{*}{5} & 2.622 & & 2.9 \\
\hline & & Bias & 1.4 \\
\hline
\end{tabular}

Table 5. Starting threshold tests

\begin{tabular}{c|c|c|c}
\hline $\begin{array}{c}\text { Speed } \\
\text { (meter per } \\
\text { second) }\end{array}$ & $\begin{array}{c}\text { Initial } \\
\text { voltage } \\
\text { (volt) }\end{array}$ & $\begin{array}{c}\text { Final } \\
\text { voltage } \\
\text { (volt) }\end{array}$ & $\begin{array}{c}\text { Change } \\
\text { (degree) }\end{array}$ \\
\hline 0.25 & 2.309 & 2.471 & 11.7 \\
\hline 0.25 & 2.316 & 2.472 & 11.2 \\
\hline 0.25 & 2.313 & 2.471 & 11.4 \\
\hline 0.14 & 2.312 & 2.468 & 11.2 \\
\hline 0.14 & 2.312 & 2.453 & 10.2 \\
\hline 0.14 & 2.313 & 2.453 & 10.1 \\
\hline
\end{tabular}




\section{Damping Ratio}

Table 6 shows the results of all damping ratio tests for the azimuth function at 5 and 10 meters per second. It is interesting to note that there is a measurable difference in the clockwise (cw) and counterclockwise (ccrv) values of the damping ratio. This is probably due to the orientation of the Model 1585 vane assembly on the side of the rotating hub. When a clockwise release is made, the vane assembly responds better since less upstream flow obstruction is present. For a counterclockwise release, the vane assembly travels through air that has been altered clue to upstream obstructions caused by the hub and vane assembly. The net result of the upstream flow obstruction of the hub and vane assembly is to decrease the air flow around the sensor just enough to inhibit the vane to respond as efficiently to the instantaneous wind direction change specified in the damping ratio tests. The counterclockwise releases tend to have a slightly greater overshoot whereas the clockwise releases respond more efficiently to the tunnel flow.

The mean value of all of the damping ratio tests for the prototype is 0.39 which is within 0.01 of 0.4 as required by regulatory guidance.

\section{Delay Distance}

The delay distance for the prototype was tested at 5 and 10 meters per second. Table 7 summaries the results of these tests. The mean delay distance of all tests was 0.72 meter, which implies that turbulent eddies of 0.72 meter in length can be observed or resolved with prototype vane assembly.
Table 6. Values of the damping ratio

\begin{tabular}{|c|c|c|c|}
\hline $\begin{array}{l}5 \text { meters } \\
\text { per second }\end{array}$ & & \multicolumn{2}{|c|}{ Clockwise (CW) } \\
\hline Run1 & & 0.37 & \\
\hline Run2 & & 0.41 & \\
\hline Run3 & & 0.41 & \\
\hline Run4 & & 0.41 & \\
\hline \multirow[t]{2}{*}{ Run5 } & & 0.45 & \\
\hline & Mean & 0.41 & \\
\hline $\begin{array}{l}5 \text { meters } \\
\text { per second }\end{array}$ & & \multicolumn{2}{|c|}{ Counterclockwise (CCW) } \\
\hline Run1 & & 0.37 & \\
\hline Run2 & & 0.34 & \\
\hline Run3 & & 0.32 & \\
\hline Run4 & & 0.35 & \\
\hline \multirow{3}{*}{ Run5 } & & 0.34 & \\
\hline & Mean & 0.34 & \\
\hline & \multicolumn{2}{|c|}{$\begin{array}{l}\text { Mean } 5 \text { meter per second } \\
\mathrm{CW} \text { and } \mathrm{CCW}\end{array}$} & 0.38 \\
\hline $\begin{array}{l}10 \text { meters } \\
\text { per second }\end{array}$ & & \multicolumn{2}{|c|}{ Clockwise (CW) } \\
\hline Run1 & & 0.41 & \\
\hline Run2 & & 0.41 & \\
\hline Run3 & & 0.40 & \\
\hline Run4 & & 0.37 & \\
\hline \multirow{2}{*}{ Run5 } & & 0.41 & \\
\hline & Mean & 0.40 & \\
\hline $\begin{array}{l}10 \text { meters } \\
\text { per second }\end{array}$ & & \multicolumn{2}{|c|}{ Counterclockwise (CCW) } \\
\hline Run1 & & 0.37 & \\
\hline Run2 & & 0.37 & \\
\hline Run3 & & 0.37 & \\
\hline Run4 & & 0.38 & \\
\hline \multirow[t]{4}{*}{ Run5 } & & 0.38 & \\
\hline & Mean & 0.37 & \\
\hline & \multicolumn{2}{|c|}{$\begin{array}{l}\text { Mean } 10 \text { meters per second } \\
\mathrm{CW} \text { and } \mathrm{CCW}\end{array}$} & 0.39 \\
\hline & \multicolumn{3}{|c|}{ MEAN OF ALL TESTS $=0.39$ or 0.4} \\
\hline
\end{tabular}


Table 7. Delay distance values

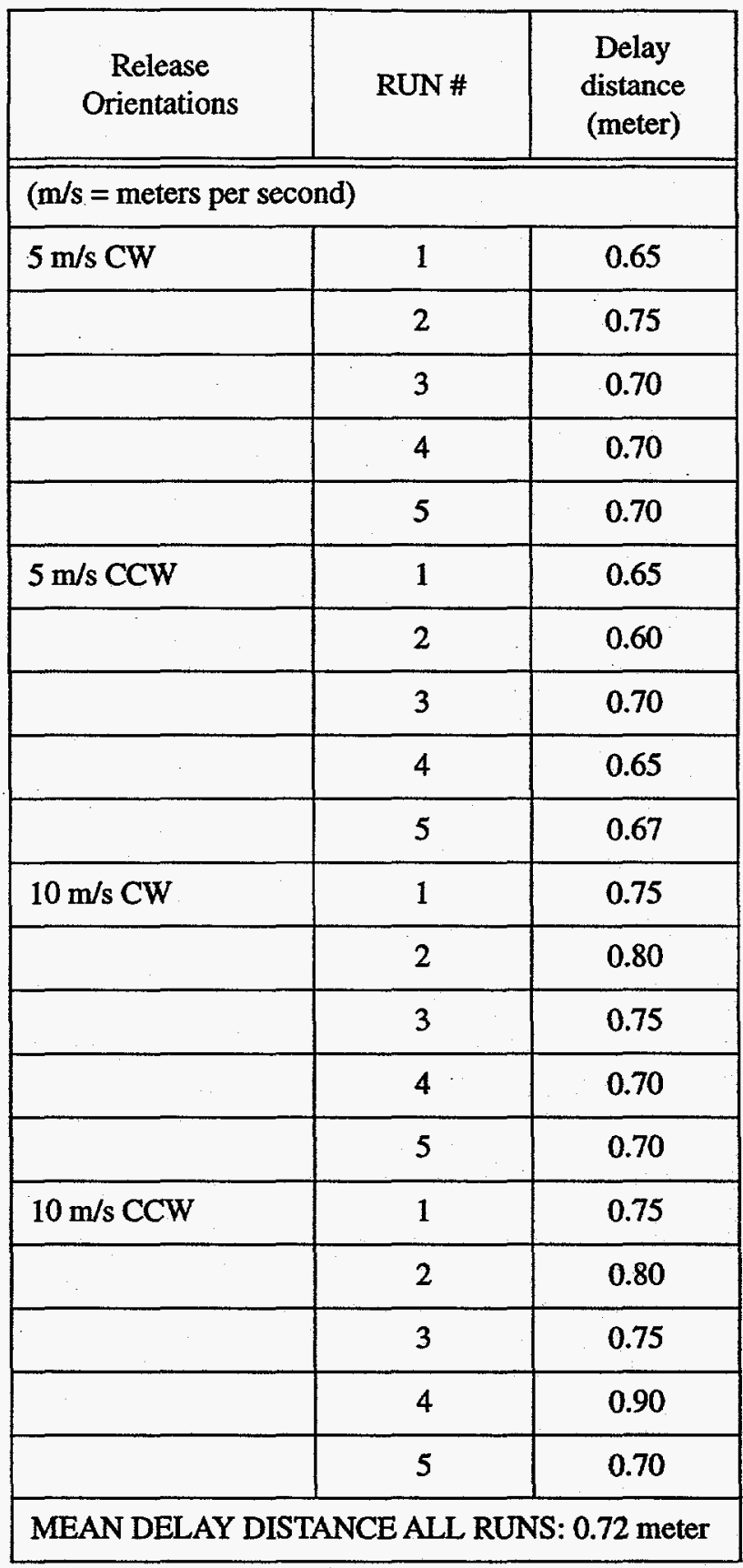

\section{Comparison to Goals and Conclu- sions}

A prototype vane assembly for a Met One Model $1585 \mathrm{Bi}$ Directional Wind Vane was created and tested under a Cooperative Research and. Development Agreement (CRADA) between Westinghouse Savannah River Company and Met One Instruments, Incorporated. The design of the vane was an incremental improvement on the previous design, which reduced the development costs of creating several prototype die-casts. The mass of the vane fins and counterweight were reduced and the fin design was changed to a teardrop shape compared to an angular design.

Consensus agreement during the initial meeting between Met One and WSRC concerning the preferred specifications for the prototype vane were detailed. In summary, the goals were to build a vane that was more sensitive to lowwind speeds and more responsive to quick wind shifts (damping ratio). The vane also was required to be attachable on the existing Model 1585 bivane instrument and maintain all other characteristics such as accuracy and durability.

The prototype vane exhibited strengths and weaknesses during extensive wind tunnel tests. The starting threshold of the vane was found to be less than 0.14 meter per second which far exceeds the goal to surpass 0.25 meter per second. The delay distance was 0.72 meter which is only negligibly higher than the goal of 0.7 meter. The damping ratio was 0.39 which is 0.4 to one significant digit as required by regulatory guidance. However, the goal was to achieve a damping ratio of 0.45 or greater.

*The relative accuracy for both the azimuth and elevation functions averaged to be less than 1.0 degree, which is acceptable. The vane bias was less than one degree for the azimuth and slightly over one degree for the elevation function. The vane bias for the elevation function is slightly high but could probably be decreased if similar vanes were manufactured by machine rather than by hand as is the case with the final prototype.

The durability of the final prototype vane was not tested, however, comments can be made concerning the viability of the vane for field use. The mass of the vane has been reduced to increase responsiveness at low wind speeds. The primary method of mass reduction was through the removal of the foam inserts inside the thin aluminum fins. This foam provided support for the fins which may be more vulnerable to mishandling during shipment and during field use. It is anticipated that the new vane will only be slightly more susceptible to hail damage than the previous version vane assembly design. The increased ability of the vane to respond to low wind speeds will likely outweigh the slightly decreased durability.

The construction of the prototype vane should be durable enough to withstand wind speeds above 33 meters per second although only cursory tests at approximate meters per second were made in the $735-7 \mathrm{~A}$ wind tunnel. The vane did not appear to have any problem in the sustained air flow of 22 meters per second. 
Table 8. Goals versus actual specifications of the final prototype

\begin{tabular}{|l|l|l|l|l|}
\hline \multicolumn{1}{|c|}{ Specification } & \multicolumn{1}{|c|}{ Goal } & \multicolumn{1}{|c|}{ Actual } & \multicolumn{1}{c|}{ Assessment } & \multicolumn{1}{c|}{$\begin{array}{c}\text { Regulatory } \\
\text { Compliance }\end{array}$} \\
\hline \hline Damping Ratio & 0.45 or greater & $0.39(0.4)$ & Not attained & Acceptable \\
\hline Starting Threshold & $\begin{array}{l}0.25 \text { meter per sec- } \\
\text { ond }\end{array}$ & $\begin{array}{l}<0.14 \text { meter per } \\
\text { second }\end{array}$ & Exceptional & Acceptable \\
\hline Delay Distance & 0.7 meter or less & 0.72 meter & Acceptable & Acceptable \\
\hline Relative Accuracy & 1.0 degree or less & $<1.0$ degree & Acceptable & Acceptable \\
\hline $\begin{array}{l}\text { Vane Bias (horizon- } \\
\text { tal) }\end{array}$ & 1.0 degree or less & 0.8 degree & Acceptable & N/A \\
\hline $\begin{array}{l}\text { Vane Bias (vertical) } \\
\text { *The relatively high value of the vertical vane bias will likely be reduced with machining during production. }\end{array}$ \\
\hline
\end{tabular}

\section{Acknowledgments}

The work performed for this project was funded by the US Department of Energy under Contract DE-AC0989 SR18035 and by Met One Instruments, Incorporated in Grants Pass, Oregon.

\section{References}

ASTM, 1991, "Standard Test Method for Determining the Dynamic Performance of a Wind Vane", D5366-95 in volume 11.03, Atmospheric Analysis; Occupational Health and Safety; Protective Clothing, American Society for Testing and Materials, Philadelphia, PA.

EPA, 1995, "Quality Assurance Handbook for Air Pollution Measurements Systems", Volume IV: Meteorological Measurements (as revised March, 1995), EPA/600/R-94/ 038d, U.S. Environmental Protection Agency, Office of Research and Development, Washington, DC.

Finkelstein, P. L., 1981, "Measuring the Dynamic Performance of Wind Vanes", Journal of Applied Meteorology, Vol. 20, pp. 588-594. American Meteorological Society, Boston, MA.
MacCready, P. B. Jr., and H. R. Jex., 1964, "Response Characteristics and Meteorological Utilization of Propeller and Vane Wind Sensors", Journal of Applied Meteorology, Vol. 3, pp. 182-193. American Meteorological Society, Boston, MA.

Parker, M. J. and R. P. Addis, 1993, The Meteorological Monitoring Program at the Savannah River Site, WSRCTR-93-0106, Savannah River Technology Center, Westinghouse Savannah River Company, Aiken, SC 29808.

Wieringa, J., 1967, "Evaluation and Design of Wind Vanes", Journal of Applied Meteorology, Vol. 6, pp. 11141122. American Meteorological Society, Boston, MA.

Wieringa, J. and F. X. C. M. van Lindert, 1971, "Application Limits of Double-Fin and Coupled Wind Vanes",. Journal of Applied Meteorology, Vol. 10, pp. 137-145. American Meteorological Society, Boston, MA. 